the geology, but of the physical geography of India, in connec. tion with a map of its hill ranges, that has nothing geological about it. It is in this expressly geographical part of the manual that $I$ find the greatest range of snowy peaks in the world omitted from a geographical notice and delineation of the Himalaya. I did not allude at all to geology.

Mr. Medlicott contends that the omission was due to the irrelevancy of the great range to the matter in hand. But how can a great range of the Himalaya be irrelevant to a geographical description of that mass, or to a special map of the hill ranges of India? And why should a prominent and leading feature be treated as a mere incident? In fact the omission was plainly due to the survival of an old error or "antiquated theory," which confused the snowy peaks seen from the Indian plains for the most part with the water-parting of the Sanpu and Ganges basins, although the latter really forms a distinct but parallel range further to the no:th. In these days a clear understanding of the superficial or geographical aspects of the mountains on the frontier of India cannot be overrated. The statesman, the warrior, and the trader alike stand in need of it ; and misleading or confused representations of the subject may become of serious moment. The ignored range is indeed to a great extent the limit of the Tibetan Plateau and of the Chinese Empire, the relations of which with India are rapidly rising into importance.

Mr. Medlicott's appeal to "the great gneissic axis" is not less unfortunate than the argument which he derives from "irrelevancy." If "the great gneissic axis" divides on the west of the Sutlej, it may be presumed to be intact on the east of that river, where in consequence it would be the more entitled to delineation and notice. But the only parts of the Southern Himalaya inserted in Mr. Medlicott's map of the Hill Ranges, are the Pir Panjal and Dlaaladhar, on the west of the Sutlej. Is there any ground for identifying "the great gneissic axis" with the Northerr Himalaya, which alone is delineated east of the Sutlej, in preference to the Southern Himalaya which is omitted? It is enough to say that neither of those ranges has been stufficiently explored, to admit of a general conclusion on the subject. Therefore it is fair to add that even geologists must refrain for the present from accepting $\mathrm{Mr}$. Medlicott's dictum in that respect.

Mr. Medlicott's penultimate sentence baffles my best efforts to understand it. It seems to be meant to be applicable somehow to the region between the Indus and Sutlej.

In conclusion I can find no good ground for treating the views of geographers and geologists as wide apart, merely because a great geographical fact has been neglected in an important geological work; and I hope that the omission will be rectified in future editions.

TRELAWNY SAUNDERS

\section{On Halley's Mount}

PERMIT me to mention two suggestions which have been made with reference to the article "On Halley's Mount" in NATURE, vol. xxi. p. 303 , viz. :-

I. That some mention should have been made therein relative to Dr. Halley's official investigations (vide Phil. Trans., vol. $\mathrm{x}$ vii. p. $960, \mathbf{1 6 9 3 )}$

2. That it was not at Dr. Halley's private expense ${ }^{1}$ that the "Principia" was published, although it was in consequence of his urgent persuasion that Newton produced his great work (cf. Preface to the "Principia").

It may be $r \in$ marked that there is a biographical sketch of Edmund Halley in Mr. Crookes's Monthly Fournal of Scicnce for February, and that the Astronomer-Royal has signified his hearty approval of the idea of the proposed monument in St. Helena.

The Writer of The Article "ON Halley's Mount" 2, Fastern Villas, Anglesea, Gosport

\section{"A Speculation Regarding the Senses"}

IN a letter bearing this title (NATURE, rol. xxi. p. 323) your correspondent, "M.," while indulging in a most extraordinary "speculation," observes that it is " not without some encouragement in actual fact." He then adds: "The ascertained facts of clairvoyance and mesmerism are what I have more especially in view, \&c. Now, whatever may be the case with clairvoyants, I think, to quote from "M.," that it must certainly "require some peculiar state of mental calm" to enable a man, when writing in a journal professedly scientific, thus quietly to assume

${ }_{\mathrm{L}}$ As inferred from Whewell's "History of Inductive Sciences." the truth of all the astounding class of phenomena to which he alludes as "ascertained facts." Clairvoyants, spiritualists, $e t$ hoc genus omne, often complain that scientific men are arrogant in their treatment of, or allusions to, the alleged marvels of the modern séance; and if we have regard to the jaunty manner in which Dr. Carpenter rides his favourite hobby along "the high priori road," I do not deny that the spiritualists have sufficiently good ground for complaint. But let them not meet arrogance with arrogance, or speak about facts which, at the best, are highly doubtful as facts which have been "ascertained."

My object, however, in writing this letter is not controversial. I desire merely to represent to "M.," and any other of your readers who may believe in the alleged phenomena of clairvoy ance, that it is their duty to have these "facts" properiy sifted, examined, and published. I have myself taken a good deal of trouble to investigate the subject, and, while meeting with a vast amount of humlug, have also met with one or two things that I am unable satisfactorily to explain. I therefore desire to prosecute my researches in this direction, without either bias or prejudice, should I be able to meet with suitable material. If "M." and his friends are right, and if I should satisfy myself that they are so, I should give a wide publicity to my methods and my results. If the phenomena should admit of repetition, I should have them witnessed and attested to by a selected number of the leading scientific men of the day. It would then be time for "M." to speak abont such "facts" as "ascertained."

Here, then, is a fair offer by "a man of science" to investigate any or all of "the powers of darkness" without any feelings of animosity against them. Will any clairvoyant or spiritualist: who really believes in his own belief supply me with an opportunity of so doing? Any letters addressed to the care of the Editor of NATURE will be forwarded to me. F.R.S.

\section{Perforated Stones in River Beds}

TRAVELLING some months ago among the Cumberland lakes, I was walking with a friend in advance of our conveyance through a narrow road, when my attention was suddenly arrested by the presence of some interesting shells and stones on the window-sill of a peasant's cottage. Stopping to admire them, or rather having taken some of them up in my hand, the woman of the house-an intelligent person-came out, whereupon I apologised for my seeming rudeness, and asked where she got them. She at once accepted my apology, and added that they, pointing to the shells and stones, were often looked at by other travellers. She further added that they were common enough in tlie Derwent River hard by, and she made no difficulty at all about accepting sixpence for the two of them I selected.

Now as I have travelled a good deal in the public service and otherwise, and seen many mountain and other streams in my day, without ever meeting any of these perforated stones, I would like to know if they occur elsewhere, and if so under what circumstances. The Derwent, a comparatively small and gentle stream, flows, as we all know, through the beautiful valley of Borradale into the pretty lake of the same name, near Keswick. I do not know anything of the geology of the district, but there are slate quarries and lead mines in the vicinity, and one of my stones partakes indubitably of the former quality. The other is as clearly a piece of granite, and if water be the sole tunnelling agent in these substances, both well illustrate the truth of the old Latin prase, "Gutta cavat lapidem, non vi, sed sæpe cadendo."

Another thing that struck me in connection with them was the extraordinary likeness of one of them, at least, to the stone axes or hatchets (I forget just now the technical name) figured by Sir John Lubbock in his " Prehistoric Times." This was so striking and obvious that, holding up the specimen, I said to my frienda gentleman connected with the Press--"Surely Lubbock must have made a mistake, and taken one of these for a prehistoric implement." Further observation only tends to confirm this first impression, and I shall be glad to hear if any similar doubt has occurred to others on sight of these objects. I will also be anxious to hear if they are as common in the Derwent or other rivers as this woman's language would imply, and I will otherwise feel obliged for such information respecting them as the courtesy or curiosity of your readers may enable them to supply. Warrington

WM. CURRAN

\section{Politics and Science}

THE Duke of Somerset, after "considering all the oppressions that are done under the sun," writes about them all, 